\title{
An Internationalist Western Labour Response to the Globalization of India and China ${ }^{1}$
}

\author{
Greg Flynn, McMaster University \\ Robert O'Brien, McMaster University
}

\begin{abstract}
Labour groups in Western countries face an immense challenge to develop a progressive international response to the economic transformation of India and China. This article develops one aspect of such a response through a consideration of the past experiences of internationalism, developments in international labour standards debates, and changes that have occurred in both international and domestic legal arenas. The first section briefly examines the notion of labour internationalism and its checkered past. The second section considers the origins and politics of the North-South divide on the issue of enforceable international labour standards. This debate highlights many of the tensions in internationalism and the difficulties of using and restraining state power. The third section considers the application of extraterritorial law to hold Western multinationals responsible for their actions in other countries. It is based primarily on a consideration of cases arising from the United States. The fourth section highlights some of the difficulties that using an extraterritorial legal approach would entail. The article concludes by speculating about the path forward.
\end{abstract}

\section{KEYWORDS}

core labour standards, extraterritorial, internationalism, labour, regulation

'The history of labour internationalism is a history of failure, of dreams disappointed, ideals compromised, and institutions corrupted' (Silverman 2000: 2).

'Yet when all such fully justified criticisms have been made, the fact remains that the working-class movement did teach, by precept, example and practice the equality of people and brotherhood of man - and woman' (Hobsbawm 1988: 15). 
The industrialization, modernization and globalization of the Chinese and Indian economies poses a series of practical and intellectual challenges for workers within these countries and for Western labour movements. The surge of a numerically large, relatively low paid and politically weak labour force into the global economy threatens to undermine existing economic protection and achievements by Western labour movements and has the potential to lead to destructive conflict between nations and states. The globalization of the US financial crisis in 2008-2009 generates further challenges with the prospect of a global recession or even a depression. The downturn in manufacturing industries around the world threatens employment levels in every state. As a result, governments may be tempted to spark economic growth through measures that undermine or threaten the welfare of other countries. The beggar-thy-neighbour policies of the 1930s could reappear and further exacerbate the present crisis.

Is it possible for workers to coordinate action to advance their position globally? The options available to workers are often presented as falling into one of two camps. Workers can cooperate with 'their' companies or their states to ensure local and national competitiveness or they can attempt to cooperate internationally to limit the exploitation of corporations and states. The choice often appears to be between nationalist or internationalist strategies. However, the real challenge is not to choose between these strategies, but to integrate them. Advocates for an alternative form of globalization and a movement of movements need a progressive state to defend and advance their interests. Advocates of nationalist development must find a way to tame the chauvinistic elements of nationalist policy or they risk having worker's interests overwhelmed at home and sacrificed abroad.

Several of the articles in this special issue stress the importance of a developmental state and the view that 'International labour solidarity is a value worth striving for, but it cannot be the primary basis of action against neoliberalism or neoliberal globalism' (Bowles and Harriss 2008: 4). The counter argument is that a nationalist development strategy cannot be the primary basis of action for global labour emancipation. Nationalist development strategies rely upon particular international environments that are either highly exploitative of other countries or require an external enemy for cohesion amongst key states. In the first case, nationalist developmental success serves the interest of a particular nation and particular workers in that nation at the expense of other nations and workers. For example, securing the resources for the European welfare state required the exploitation of other parts of the world. Such a strategy might further the interests of one groups of workers, but it undermines the interests of many others. Alternatively, a strategy that contains some mechanism for cohesion among workers and which more evenly shares the costs and burdens of development may require the presence of an external enemy. One example of this form of strategy is that of the East Asian developmentalist state in the post-1945 era. However, a closer examination reveals that the East Asian miracle was contingent upon one trading partner, the United States, being willing and able to supply the capital for this development and provide an open market for Asian exports (Stubbs 2005). This strategy in turn was motivated by the Cold War confrontation between capitalist and communist states. A very 
threatening external enemy was required before the cooperative policies which fostered the developmental state could be put in place. While both these development strategies have enjoyed considerable success in their home regions, that success has been dependent upon either external exploitation or driven by other political and strategic considerations.

If one group of states opts to pursue economic development through an export oriented approach, other states have to be willing to import their goods and services. The dilemmas presented by each of the two development strategies remains. In the absence of an external enemy or some other political or strategic consideration to foster economic goodwill between potential trading partners, what motivation can cement the bargain? Alternatively, if states opt to pursue autonomous development strategies, how can they be prevented from becoming exploitive, exclusionary and chauvinistic? A third, more appealing option is the development of an internationalist labour strategy for furthering the interest of workers on a global basis. This approach requires a state that will defend and advance the interest of its own workers, but not at the expense of workers in other states. In this regard, the nationalism of the developmental state (in the South or the North) must be restrained by the internationalism of its workers and the labour movement. The difficulty that arises with such an approach is that internationalism is not a sentiment that is either natural or robust for the labour movement and, as such, it must be fostered through deliberate and practical action. It is also the reason why labour internationalism cannot be an afterthought that follows the developmental state, but rather must be forged in a conjunctive fashion.

In light of a need to integrate national and international impulses, this article develops a progressive internationalist response that could be adopted by Western labour movements as both China and India continue their historic paths of transformation. It combines a recognition that state power is needed to improve labour conditions, but advocates that such power only be deployed in a way that does not threaten workers in other countries. In particular, it argues that one fruitful way forward for Western labour movements is to put increased energy into changing domestic legal environments so that Western based trans-national corporations (TNCs) can be held accountable in their home countries for the labour violations of their foreign subsidiaries and sub-contractors. This is a difficult and complicated task, but putting more emphasis on such a strategy is likely to further labour internationalism and the attempt to integrate nationalist and internationalist strategies.

The challenges of altering domestic legal regimes are immense. The importance and possibilities of such an approach can be highlighted through a consideration of the past experiences of internationalism, developments in labour standards debates and practices and changes that have occurred in both international and domestic legal arenas and the consequences arising there from. The first section of this article briefly examines the notion of labour internationalism and its chequered past. A sense of history will allow us to consider the lessons of the past. The second section considers the origins and politics of the North-South divide on the issue of enforceable international labour standards. This debate highlights many of the tensions in internationalism and the difficulties of using and restraining state power. The third section considers the application of extraterritorial law to 
hold Western multinationals responsible for their actions in other countries. It is based primarily on a consideration of cases arising from the United States. The fourth section highlights some of the difficulties that using an extraterritorial legal approach would entail. The article concludes by speculating about the path forward.

\section{Labour Internationalism}

Over the past two centuries, internationalism has taken a number of different forms, ranging from the dogma of free trade liberals and the advocates of humanitarian intervention to the alleged civilizing mission of imperialists and missionaries to the revolutionary slogans of workers, republicans and Islamists (Halliday 1988, Lynch 1999). In practice, internationalist interventions range from providing humanitarian aid, to the elaboration of utopian projects, to the use of violence to suppress other societies. What all of these visions and practices of internationalism share is the notion that moral obligations extend beyond state borders and that the state itself is not always the best instrument for the furtherance of universal goals. An Internationalist orientation entails a concern with the fate of people in other parts of the world and an obligation to act upon those concerns.

Labour internationalism is one variant of being concerned with the lives of people outside one's own state's boundaries. The nineteenth and twentieth centuries have featured extensive international projects by workers' organizations and socialist parties. Most visible were the First (1864-1876), Second (1889-1917) and Third Internationals (1919-1943). ${ }^{2}$ These internationals were influenced by a variety of anarchist, Marxist, social democratic and communist groups (Forman 1998). They varied in their structure and reach, with the First and Second Internationals being federal structures that were mostly confined to Europe, while the Third was world spanning, but tightly controlled by the Soviet state. Despite differences, these labour internationalist groups shared two key features (Colas 1994). First, they were reactions to concrete problems facing workers, ranging from the need to deal with strike-breaking by foreign workers, to creation of labour legislation to the defence of socialist revolutions. Second, the Internationals struggled to reconcile the solidarity of workers with the demands of nationalism. Most strikingly, the Second International foundered as Europeans rushed to war in 1914 while the Third International evolved into a foreign policy tool of the Soviet Union.

Today, groups interested in improving labour conditions, whether they be trade unions, labour oriented NGOs or concerned consumers, face the same basic problem of internationalism. How is one to reconcile the need and desire to show solidarity with the force of nationalist politics and inclinations? The history of the three Internationals flag three key dangers to be avoided. The first is the problem of Western ethnocentricism. The First and Second Internationals were European organizations that did not greatly engage with the outside world and were largely ignorant of the dynamics and lives of other regions. The second danger is the risk posed by the threat of war and mobilization for war. The Second International collapsed because its members were swayed more by the call to arms than by the call to peace. This was partially due to the fact that the socialist project was so closely 
associated with the nation building project that engaging in war to protect the nation seemed logical. The Third International showed the danger of linking an internationalist project to the needs of a particular state's foreign policies. Workers' interests around the world were sacrificed to the power politics strategies of the Soviet Union. Similar problems plagued the international role of the US labour movement during the Cold War (Sims 1992, Thompson and Larson 1978).

The twenty-first century is unlikely to see a reincarnation of the formal labour and socialist Internationals of the nineteenth and twentieth centuries. Today's internationalism takes a much different organizational form in that it is decentralized, networked and heavily reliant on information technology communications (Waterman 1998). This revival of labour internationalism after the Cold War could benefit from a consideration of past experiences. In Western countries an effort should be made to construct an internationalist approach that is sensitive to the views of workers in other parts of the world, avoids actions that increases political tensions between states and resists being an accomplice of the unsavoury aspects of their own state's foreign policy.

How can the labour movement move from these rather general abstract points about labour internationalism to the difficult issue of achieving enforceable international labour standards? The campaign to secure enforceable international labour standards has been a central element of the international union movement's attempt to deal with neoliberal globalisation. The next section examines the recent history of these efforts in an attempt to establish the limits of that project and highlight the lessons it poses for a renewed internationalism approach.

\section{International Labour Standards and the North-South Divide}

International labour standards emerged as a key issue of debate between and amongst states and civil societies in the North and South in the early 1990s. The debate centred around the creation of mechanisms which would lead to the enforcement of core labour standards or 'enabling rights', including: freedom of association, collective bargaining, freedom from forced labour, abolition of child labour, and freedom from discrimination. ${ }^{3}$ These rights are referred to as enabling rights because they are seen as the basic minimums that allow workers to organize their affairs and participate as partners in economic negotiation and regulation. Enabling rights do not confer all of the other labour protections advocated by the International Labour Organization (ILO), but they do allow workers to pursue those rights from a position of stability and independence.

International labour standards have become a significant issue because state and corporate economic strategies in the North and the South have increasingly relied upon cheap and passive labour as a source of development and profit. Since the debt crisis of 1982 and the collapse of Communism in the Eastern Europe in 1989, most developing countries have abandoned the notion of autonomous development in favour of finding a niche in the global economy, often through export oriented industrialization (McMichael 2007). The key to development in this context is seen to lie in attracting foreign direct 
investment to build factories to export goods, resources and occasionally services to the North. Northern countries have increasingly relied upon imports from several key Southern countries to provide cheap mass consumer goods. These imports allow steady levels of consumption in the face of stagnant real wages and also reduce the risk of inflation as costs of many consumer products remain stable or decline over time. Transnational corporations are the key vehicles for these economic strategies as they possess the ability to channel the movement of investment into productive enterprises in numerous locations and manage the distribution of the end product. In this evolving economic environment, international labour standards have been brought to the forefront.

In Northern states, three factors have led to the issue of enforceable labour standards becoming more prominent. First, the decline of the standard employment relationship with the advent of increasingly insecure, low waged employment has corresponded with a flood of manufactured goods into northern states from the South (Vosko 2000). The second factor has been the rise of social movements concerned with ethical consumption. In particular, the rise of information technologies which facilitate global production have also allowed workers and consumers to communicate about the conditions under which products are created. A growing number of consumers have decided to accept responsibility for the impact of their spending decisions on workers and the environment in other parts of the world (Blowfield 1999). The third factor has been a more general debate over global regulation and the public interest. The lack of protection for basic worker rights is contrasted with the elaborate new protections Western corporations have secured for intellectual property rights (Sell 2005).

In many Southern countries the issue of labour policy is extremely sensitive for three major reasons. First, because many developing states have based their development strategy on exporting low cost products to advanced industrialized states, changes in the labour standards regime threaten to undermine one of the cornerstones of their competitive advantage - low wages. Second, many developing countries have historically experienced Northern protectionism in the international trade regime (Williams 1994). They suspect that the labour standards issue will only be the latest incarnation of Northern protectionism. A third reason is that many developing countries have export models based upon an authoritarian political culture which systematically excludes labour from decision making. This was certainly a feature of the East Asian development state (Deyo 1993). Respecting core labour standards or 'enabling rights' risks empowering groups that may become political opponents of existing regimes. One need only look at the role that trade unions have played in spreading democracy in countries as diverse as Poland, South Korea, South Africa and Brazil to see that this fear is justified (Adler and Webster 1995, Bielasiak and Hicks 1990, Eder 1997).

Despite the prominence to which these issues have arisen, labour groups have largely failed to link social and economic rights on the international stage (O'Brien et al 2000, O'Brien 2008), and the efforts to do so have highlighted the political divisions over the issue. The politics around the labour standards debate are complex and cut across state, corporate and class lines. While it is often portrayed as one in which Northern states advocate for labour standards and Southern states resist, this is a mistaken over-simplification 
of the debate. A better reading of the situation, and one which could potentially assist in developing a more collaborative approach to the issue in the future, would group advocates and opponents of enforceable labour standards into three different camps - those strongly in favour (proponents), those who will accept and implement labour standards under pressure or rewards (conflicted) and those strongly opposed (opponents) - and establish the motivations of the various actors for their positions.

\section{I) PROPONENTS}

The group strongly in favour of enforceable global labour standards includes virtually all trade unions in Northern states and many trade unions in Southern states, social democrats in various states and the leadership of traditionally social democratic states, such as the Nordic countries. This group believes that the state must play a role in ensuring fair working conditions. In a global marketplace, action is needed to have global regulation. The primary approach of this collection of interests is an attempt to ensure that international economic agreements and institutions contain provisions that mandate adherence to core labour standards.

In terms of motivation, it is not surprising that social democratic states would seek labour standards at the international level. Ideologically, they are predisposed to creating a social democratic partnership between states, capital and labour on an international basis which mirrors the consensus they have forged domestically. They see respect for labour standards and economic development as complimentary with one another. Ideology and politics aside, social democratic states may also possess some material interest in the issue, since the spread of labour rights should raise labour costs in other countries and marginally reduce the competitive pressure on wages in Northern states. The rationale of Northern trade unions in support of enforceable standards is easily predictable. They seek international labour standards both on principle and because of material interest. They are committed to the spread of an industrial relations model that grants similar rights to all workers and they seek protection from the competition of labour which cannot represent its own interests. In Southern countries, there is also a constituency for international labour rights, particularly in countries with highly organized independent militant labour unions such as COSATU in South Africa and CUT in Brazil. These unions are accustomed to collective bargaining, making deals and working within regulatory frameworks. They are also motivated by the need for protection from the competition generated by unregulated capitalism and see labour standards as one element to advance their goals.

\section{II) CONFLICTED}

A second group contains actors that are either amenable to or have an ambiguous position to global labour standards. For example, the United States has both advocated the adoption of core labour rights and taken steps which cast doubt on its commitment to them. The US government has been a prominent voice for labour standards at the WTO, but has always been willing to trade those standards off against other commercial gains. The US itself 
has not ratified all of the ILO's core labour standards conventions and makes some rights difficult to achieve. There are differing interpretations for this behaviour. One is that the US government is hypocritical and protectionist, in that it only advances labour rights to protect its own markets or gain commercial advantage. The other interpretation is that the subject of labour rights is still controversial within the US and a system of divided government leads to the simultaneous pursuit of contradictory policies.

There are a number of corporations that can also live with or, in some cases, even thrive in a world of regulated labour standards. These corporations are motivated by the fact that they compete on the basis of quality or brand name. For some of these corporations, labour is a relatively small amount of their overall costs so they can afford measures which increase labour costs. Other corporations may actually use respect for labour or environmental standards to bolster their brand image and thereby charge a premium for ethical behaviour and use it as a competitive advantage over those firms that fail to comply with such standards. Several prominent retailers have carved out such a strategy such as Mountain Equipment Co-op in Canada and American Apparel in the United States.

A large question mark hangs over the political position of citizens in Northern countries. On the one hand, the lack of labour standards in many Southern countries may threaten the employment prospects, bargaining power and sensibilities of Northern workers and consumers. On the other hand, the cheap products produced by such labour allows consumers to enjoy a higher standard of living with greater choice of products than would otherwise be possible. It is this demand for cheaper products that provides the incentive for producers to cut labour costs through any means possible. Thus, one simultaneously witnesses people flocking to Wal-Mart to buy Chinese made products and a consumer movement for ethical consumption. Northern citizens remain a pivotal group in the struggle over international labour standards.

There are a number of labour groups in the South that are also in an ambiguous position. They agree that labour standards need to be improved and regulated, but disagree that this should be done through a system which imposes penalties on Southern governments when labour standards are abused in their territories. For example, while many Indian trade unions wish to see basic labour rights extended, they resist linking labour standards to the WTO or other trade agreements because of their anti-imperial stance. The difficulty these groups have is that they are unable to suggest a feasible alternative enforcement mechanism.

\section{III) OPPONENTS}

The third group of actors are those that are firmly opposed to any form of international action on labour standards and their motivations in this regard are relatively self-evident. This group is composed of international business associations, corporations that compete on the basis of price alone (most subcontractors in textile, clothing, toy industries), neo-liberal states in the North, many neoclassical economists, authoritarian and/or anti-imperialist states in the South, labour organizations in the South that are either tied 
closely to their state or corporations, and the more radical anti-globalization forces that reject international enforcement of any kind.

International business associations such as the International Chambers of Commerce or national associations take a general position against international enforcement of labour standards. The general corporate position is that self-enforcement is the preferred mode of regulation. Self-regulation suits many businesses in the South and North because it allows them to utilize the difference in labour conditions across state borders to generate increased profits. This contrasts with the clash of commercial interests in fields such as intellectual property rights where Northern TNCs tend to benefit from strict enforcement whereas many of the 'violators' are located in the South. On one hand, labour is viewed as an exploitable resource while other factors of production, such as property rights, are more evidently protected.

A large obstacle to implementing international labour standards are business and consumption models based upon continually providing cheaper products. North American television commercials show a smiling yellow dot zipping through Wal-Mart stores rolling back prices. The commitment to continually reduce prices results in giant retailers demanding that their suppliers continually reduce costs. In labour intensive industries, labour costs must be contained or reduced. When technological fixes have been exhausted or ignored this means squeezing productivity from workers through reduction in wages or changes in working conditions. A large section of the retail market competes on the basis of price and suppliers compete for retailer business in a similar way. This usually means Southern workers pay the real price for cheaper mass consumption goods in the North.

Many Southern states such as India and China strongly oppose any measure which would link trade access with labour standards. Their general view is that this is yet another example of Northern states pushing a parochial concern that will be used to block imports from developing countries. Given the lack of Northern concessions on issues such as agriculture, there is no desire to address the labour standards issue. Whereas some developing countries can see advantage in some Western proposals on services opening (e.g. India), there are few that see clear benefits to labour agreements, unless such agreements focussed upon labour mobility which provided access to Northern labour markets.

Recalling the three lessons derived from the history of labour internationalism (sensitivity to the views of workers in other parts of the world, avoiding actions which increase political tensions between states, keeping a distance from one's own state's foreign policy) Western labour movements can discern a number of points from the campaign for enforceable global labour standards and the motivations of the various actors involved. While most of the opposition was generated by business associations, corporations and/or authoritarian states which would not support enforceable labour standards in any context, other opponents included actors advocating for increased economic justice between the North and South. They need to be considered as potential partners in any future strategies. The relevant points of concern include: the role of the Western consumer in pushing for lower wages by demanding cheaper products, the role of Western TNCs in pressing foreign contractors for cheaper inputs and foreign governments for cheap flexible labour markets, 
and sensitivity about attacking the policies of foreign states that represent local populations (however imperfectly).

A Western labour internationalism informed by the recent labour standards debates would recognize that while India and China are plagued by poor working conditions and labour rights issues, and these conditions impact the lives of Western workers, the causes and solutions to some of these problems lie in Western countries themselves. It would need to acknowledge the key role of Western states, corporations and civil society and accept a responsibility to exercise maximum influence first and foremost in the West.

Groups which accept that some responsibility lies with Western corporations, states and consumers have attempted two strategies. The first strategy has been to try to increase the consumption of ethically traded goods through a process of persuasion. This process involves persuading two audiences, consumers (shop ethically) and corporations (produce ethically). Both of these initiatives involve creating norms of acceptable behaviour and urging actors to conform to those standards. There is a large literature on the rise of ethical trading and corporate codes of behaviour as attempts to improve labour conditions in the global economy. What is increasingly clear is that the ethical trade initiative remains in niche markets and the corporate codes of conduct are having a limited impact on the factory floor (Bruno and Karliner 2002; Christian Aid, 2004; Rowe, 2005). Because of this lack of success, and in keeping with the theme of searching for suitable enforcement mechanisms from the international standards debate, it is argued that there should also be an increased focus on attempts to implement more formal legal sanctions against Western TNCs. The following section examines how Western countries might use extraterritorial law to regulate the foreign activities of their own multinational corporations.

\section{Using Extraterritorial Law to Discipline Western Multinationals}

The concept of 'extraterritoriality' refers to the extension of a state's domestic law and/or judicial jurisdiction to persons located outside of the state or to events that occur beyond the state's territorial borders. The extraterritorial application of state laws has usually been fairly limited because of a general presumption against the application of a country's legal sovereignty to events and persons beyond its territorial integrity. Despite this general presumption, recent years have seen an increase in the use of extraterritorial laws to create new criminal and civil liability consequences for domestic and non-domestic actors. These developments in domestic and international law provide the potential for a legal approach that could be harnessed to protect labour rights. We will begin by examining the extension of criminal law before we turn our attentions to civil law.

\section{EXTENSION OF CRIMINAL LAW TO DOMESTIC CITIZENS OUTSIDE OF STATE}

The primary rule in international law governing state jurisdiction in relation to the prosecution of crime has been the territoriality principle. It proscribes that the territorial location in which the commission of the offence occurs provides a state with the jurisdiction 
to prosecute, regardless of the nationality of the offender. (Shachor-Landau 1980: 282, Stessens 2000: 245). On this basis, there would be limited recourse in domestic legal arenas to pursue TNCs for labour violations that occurred in other countries. However, there are five exceptions to the general territoriality principle. ${ }^{4}$ The first exception is the 'objective territoriality' principle which comes into play where the criminal activity takes place outside of a state's territorial borders, but has an impact within or causes consequences inside the state itself. A common example of the operation of this exception is the hypothetical situation where an individual fires a gun from one side of an international border and injuring a person on the other side of the border. ${ }^{5}$ The country in which the individual was injured would still possess the jurisdiction to prosecute the offender under the objective territoriality principle. The second exception is the principle of 'protection' and it provides a state with extra-territorial jurisdiction where the offence in question occurs outside of a state's borders, but threatens the security of the state and/or its political or economic foundations (e.g. counterfeiting, treason). The third exception is the 'nationality' or 'active personality' principle and it endows extra-territorial jurisdiction where the criminal offence may have taken place outside of the state, but that the perpetrator of the alleged crime is a citizen of that state. In other words, states have jurisdiction under this principle to prosecute their own citizens for criminal offences regardless of where the offence took place. The fourth exception, the principle of 'passive personality', is similar in operation to the 'active personality' exception, although it provides a state with jurisdiction to prosecute an offender where the victim of the alleged extra-territorial crime is a citizen of that state.

The 'universality' principle is the fifth exception to the application of the general territorial standard, but is more properly considered as the basic principle underlying prosecution of offences in the international criminal law regime. This exception provides $A L L$ nations with the jurisdiction to prosecute offenders of a limited number of offences that are considered as international crimes, and includes crimes such as genocide, piracy, terrorism or hijacking. This exception provides that a country may choose to either prosecute an individual suspected of one of these crimes within its own jurisdiction, extradite the accused to the International Criminal Court (ICC), depending on whether it has jurisdiction to deal with the offence or offender, or to another country that is willing to prosecute the offence and has sought extradition from the state in possession of the accused.

Is there anything in this body of practice that gives hope to those who would like to use criminal law to hold corporations accountable for their activities? At the outset, it would appear unlikely. For example, it is a significant limitation on the use of an international criminal law regime that the jurisdiction of the ICC does not include corporations (Shamir 2004: 661). However, there are two sets of domestic criminal offences in which states have been willing to extend the application of their domestic criminal law, primarily on the basis of the nationality principle. In particular, Western states have increasingly recognized that they should regulate the behaviour of their own citizens on an international level, in relation to sex crimes against women and children and in relation to terrorist related activities of national citizens. 
In relation to the sex-trade, many civil law based systems have already extended jurisdiction for these types of offences beyond their own state borders on the basis of the nationality principle. This development has now also occurred in common law systems that were traditionally more observant of the territoriality principle. For example, the U.S. government enacted the Protect Act in 2003 that eased efforts to prosecute U.S. citizens committing crimes against children outside of the United States (Lichtblau and James 2004). The UK., Canada and Australia have all also similarly extended the reach of their criminal law regimes to include foreign sex crimes against children. ${ }^{6}$ Each of these provisions extends the criminal law jurisdiction of the respective countries beyond their territorial borders on the basis of the 'nationality' principle and also required the offence to be one of double criminality. ${ }^{7}$ At the same time, civil law jurisdictions that already recognized the nationality principle in relation to these types of offences have made the prosecution of extraterritorial crimes less difficult through the elimination of formal requirements, such as the filing of a criminal complaint by the victim, consent of the government of the state in which the offence occurred and/or the requirement of double criminality.

The events of September 11, 2001 and the subsequent 'War on Terror' provide a second example of where states have been more willing to prosecute their domestic citizens in relation to events that occur beyond the borders of the state, namely in relation to terrorism related offences. For example, in 2007, the United States prosecuted Chiquita Brands International, Inc., a U.S. incorporated company, for engaging in transactions with a specially-designated global terrorist group. In particular, it was alleged by the U.S. government that Chiquita, through its subsidiaries, provided cash payments to an illegal paramilitary group in Columbia, the Autodefensas Unidas de Columbia (AUC), in exchange for 'security services' in the banana producing regions in which Chiquita operated. These payments to the AUC began in 1997 after other paramilitary organizations in Columbia were designated by the U.S. government as foreign terrorists and continued an allegedly long history of Chiquita's association with these types of organizations in Columbia. Despite the fact that the Bush administration also designated the AUC as a foreign terrorist organization in September 2001, Chiquita continued to contract for security services with AUC well into 2004. The criminal charges arising out of the events in Columbia were brought about only after Chiquita self-reported the payments to the U.S. Justice Department in 2003, but still continued to make additional payments to AUC for ten months after they were advised to cease such activity by the U.S. government. The charges against Chiquita were resolved when Chiquita agreed to a plea arrangement with the U.S. government that included an admission of guilt, a fine of twenty five million dollars and an agreement that none of the corporation's executives would face criminal charges (USDDC 2007).

While both of these examples provide for the potential application and extension of domestic criminal law to events beyond state borders, it remains unlikely that such an approach will be advanced on a unilateral basis in relation to labour violations by corporations. At the corporate economic level, states have tended to work more cooperatively in their approach to the regulation and elimination of criminal conduct. Whether through harmonization of laws, the extension of authority to supranational organizations or through 
other coordinated efforts, states have sought to control unwanted economic behaviour on a multilateral basis. For example, attempts to control economic criminal conduct such as money-laundering or corrupt business practices have been addressed in the international arena through the establishment of international conventions, the creation of enforcement and advisory bodies and a harmonization of domestic criminal laws. The Convention on Laundering, Search, Seizure and Confiscation of the Proceeds from Crime and the United Nations Convention against Corruption are two examples of the international community reaching a consensus on not only the elimination of economic criminal behaviour, but also cooperative approach to the enforcement and prosecution of these types of crime (Stessens 2000, chapter 11). While one notable exception has been the application of U.S. anti-trust legislation and enforcement (Davidow 2002), it is unlikely that any one state would eschew the cooperative-based approach to unwanted economic behaviour on the part of corporate citizens. In addition, it appears that the extension of criminal jurisdiction in these two situations (sex crimes and terrorism) may have more to do with the seemingly widespread opposition to the two types of crimes involved rather than a principled approach to regulating international conduct. In this regard, the use of civil law approaches, particularly in the United States through the application of the Alien Claims Torts Act and other similar pieces of legislation that confer extra-territorial jurisdiction, may be a more successful route to pursue.

\section{EXTENSION OF CIVIL JURISDICTION TO NON-DOMESTIC ACTORS I: ALIEN CLAIMS TORTS} ACT

Generally speaking, most states will only provide civil liability jurisdiction where one of the parties involved is a national citizen or the events giving rise to the claim for liability occurred within the state. A significant exception to this proposition is the Alien Claims Torts Act which provides U.S. district courts with jurisdiction over civil actions commenced by non-citizens, in relation to violations of the law of nations or a Treaty of the United States, even where the wrongful conduct occurred outside of the United States and did not involve a U.S. actor. There are two issues that were raised by attempts to use this legislation in relation to extra-territorial events, namely: what was the scope of the Act and to whom did it apply? The first of these questions was addressed in the Filartiga case in which the U.S. Second Circuit Court of Appeal permitted a claim advanced by a Paraguayan family based on the torture and death of a Paraguayan national in Paraguay at the hands of a Paraguayan state official. ${ }^{8}$ Following the Filartiga decision a number of claims were filed in the U.S. courts by non-citizens claiming civil damages for alleged violations of the law of nations by state actors in their home countries.

The second question, as to whom ACTA applied, was addressed in the 1995 decision of Kadic $v$. Karadzic. In that case, the court extended the application of ACTA to claims brought against private or non-state actors, such as multinational corporations, for jus cogens violations and to those situations where the actions of the private defendant were sufficiently tied to state action so as to link the private individual and the state together. ${ }^{9}$ This decision was remarkable for the fact that it extended potential liability for a violation of the law of 
nations, something previously considered under international law to be only possible by a state actor, to private individuals including multinational corporations. The decision in Karadzic opened up a second wave of liability claims, this time against non-state actors, and multinational corporations in particular, alleging violations of a series of offences against the 'law of nations' including human rights and environmental claims (Ochoa 2005). In this regard, most of the claims were advanced on the basis that these private individuals were acting under state authority, had undertaken state action or were akin to state actors in perpetrating the alleged violations of the law of nations. This second wave of litigation, beginning in the mid-1990s, culminated in a series of actions that sought clarification of the requirements of 'state action' that were necessary to rest liability on multi-national corporations. The California District Court and the Ninth Circuit Court of Appeal eventually provided that clarity, describing the necessary conduct to consist of either "joint action' with the state or state officials in a violation of the law of nations or by providing 'knowing practical assistance or encouragement which has a substantial effect on the perpetration of the crime' by state actors. ${ }^{10}$ Going one step further the Court in Doe VI also found that forced labour by private corporations was a modern form of slavery and thereby constituted a jus cogens violation and therefore did not require any form of state action to constitute a violation of the law of nations and thereby attract liability under ACTA.

While the general direction in U.S. courts has been to permit claims under ACTA to proceed, the U.S. Supreme Court has subsequently provided a relatively restrictive interpretation of the scope and applicability of ACTA. The Court indicated that any claim under the 'law of nations' had to satisfy three criteria: first, it had to rest on a norm of international character; second, it had to be accepted by the civilized world; and third, it had to be defined with a specificity comparable to the features of the eighteenth century violations, meaning that it had to be specific or definable, universal and obligatory. ${ }^{11}$ On this basis, given the current state of international law, it is unlikely that traditional labour-related concerns, such as sweatshop conditions, low wages and long hours, would rise to the levels necessary to constitute violations of the law of nations as defined by the US Supreme Court (Chanin 2005).

\section{EXTENSION OF CIVIL JURISDICTION TO NON-DOMESTIC ACTORS II: HELMS-BURTON, D'AMATO AND TORTURE VICTIM PROTECTION ACTS}

While ACTA creates the potential for non-domestic actors in the US to advance civil liability claims arising out of extra-territorial events, the US has also extended its domestic legal regime in relation to claims by US citizens for events outside of US territory. In particular, the Helms-Burton Act, the D'Amato Act and the Torture Victim Protection Act all provide US citizens with causes of action in US courts against foreign citizens in relation to extra-territorial events. For example, Title III of the Helms-Burton Act provides US citizens with the right to recover damages against persons who 'traffic' in property seized by the Castro government and in which the Plaintiffs held an interest. Given that the US embargo over Cuba has been in place for more than thirty years, these provisions can only 
apply against non-US citizens in relation to transactions that occur outside of the US Notably, and in contrast to ACTA, the right to pursue a civil action under the Act is not extended to non-US citizens. ${ }^{12}$ The D'Amato Act, also know as the Iran-Libya Sanctions Act of 1996, provides a less controversial extraterritorial application of US law, given the targets of the Act and the conduct that it attempts to curtail (Smis, Stefaan and van der Borght 1999).

The enactment of these domestic laws appears to provide a potential avenue for impacting on the conduct of trans-national corporations and the enforcement of global labour standards. However, in practice, this possible remedy may be more illusory than first thought. For example, the application of the Helms-Burton and D'Amato Acts has been somewhat muted, particularly in relation to title III of the Helms-Burton Act. While the US embargo over Cuba continues and a number of persons have been refused entry into the United States under the Act, Presidents Clinton and Bush both continuously suspended the application of the civil liability provisions, a stipulation that has been fatal to purported liability claims. The political controversy generated in the international community by the passage of the Helms-Burton Act and the D'Amato Act in relation to the activities of non-US citizens for events and transactions that occur outside of US borders and that have nothing to do with the US, has limited the effectiveness of the use of this type of extraterritorial application of domestic law as a vehicle to achieve international policy goals. The Torture Victim Protection Act, enacted by the US Congress in 1992, has received little attention in relation to its extraterritorial application. While the Act creates a civil cause of action and allows for jurisdiction in US courts in relation to state action that constitutes torture and extra-judicial killings, it also contains some inherent limitations in that it requires plaintiffs pursue all available remedies, including civil liability claims, in the jurisdiction in which the torture occurred before proceeding under the Act. The Act also includes a fairly restrictive ten-year statute of limitation, thereby precluding many claims of an historic nature. In addition, the Act has not been employed by Plaintiffs to a great extent and the actions that have been brought under this provision have been advanced primarily against states that were deemed to be terrorist states by the US government and therefore not subject to the Foreign Sovereign Immunity Act. ${ }^{13}$

This brief review of the extra-territorial application of domestic law indicates that attempts to pursue international policy goals through the successful use of domestic legal regimes has been relatively limited. However, the review also demonstrated that there have been at least three developments which provide some possibility that these avenues could be used to hold corporations accountable for their actions in other states. First, the nationality principle that states can hold national private actors accountable for the commission of certain types of crimes in foreign states is most clearly illustrated in the evolution of sex crimes laws. There is no reason to suggest that this principle could not be extended to other types of offences as well. Second, some national security and anti-terrorism provisions can be used to hold corporations responsible for assisting groups engaged in terrorising foreign populations. Third, in some narrow cases foreign residents and US citizens can both use the 
US civil law system to hold corporations accountable for acts committed outside the United States.

\section{Obstacles and Problems of Using Extraterritorial Laws}

Despite the potential that the application of domestic legal regimes provide for extra-territorial events, immense hurdles remain in actually using this approach to successfully pursue enforceable labour standards on a global basis. There are at least five general obstacles to the extra-territorial application of domestic law that limit this potential. To begin, the primary criticism against any form of extraterritoriality is that it is an infringement upon the sovereignty of other countries. This can result in strained diplomatic and trading relations between states and the use of retaliatory measures by effected states to alleviate the impact of the extraterritorial laws, as is evidenced by the international community's response to the Helms-Burton Act, and thereby undermine the effectiveness of this approach.

A second criticism of the use of extraterritorial laws is that it leads to a lack of predictability and consistency for private actors in the international arena. Global corporations are expected to be aware of the laws that emanate from their own domestic jurisdiction, but must also be cognizant of the laws applied by other countries to international transactions. Given the divergent strategies employed by states around the world to address various policy problems, this difficulty raises more than just a concern over the cost of doing business, but also interferes with the ability of these organizations to plan their affairs and generates the potential for a lack of fairness by the enforcement of legislation that was not foreseen. ${ }^{14}$ The extension of competing domestic law regimes into the international market creates the real possibility of the enforcement of laws that directly conflict and contradict one another. Not only does this potential create unfairness to the organization that must choose which law it will violate, but it also serves to undermine the policies that underlay those measures by ensuring that, at least in some circumstances, the purposes of the legislation will not be achieved.

A third obstacle to the use of extraterritorial laws against TNCs is that corporations will attempt to sabotage their application. In particular, corporations will structure their transactions and affairs in such a manner so as to avoid a jurisdiction altogether, with a concomitant effect of lessening investment and commercial activity in that jurisdiction and consequent economic repercussions that flow from that loss of economic activity.

A fourth difficulty with extraterritorial approaches is the inherent legal nature of the enforcement measures, and in particular the necessity of collecting evidence. In some states and in some circumstances, the gathering of sufficient evidence to meet the requisite standard of proof will be particularly difficult, depending on the relationship between the nations in question, the transient nature of the parties involved in the events or transactions, the types of offences that are alleged, and the willingness of victims and other witnesses to participate in the process (Collingsworth 2003).

The last difficulty that arises in relation to the pursuit of legal approaches in an extraterritorial fashion is the nature of the purported defendants to the criminal and civil 
actions. In particular, most of the private actors in the international arena are TNCs and the law, in most states, deems these 'legal persons' and each of their subsidiaries as separate legal entities (Wilson 2006: 53). As such, in the absence of direct participation in the alleged events by the parent company, criminal or civil liability that is incurred by a subsidiary is usually not attributable to the rest of the multinational corporation (Blumberg 2001: 301-307). This has two significant ramifications. First, personal jurisdiction for civil claims and jurisdiction in general for criminal prosecutions may be difficult, if not impossible, to assert over foreign subsidiaries that have no direct relationship with the state claiming jurisdiction. ${ }^{15}$ Second, even if a court were able to acquire jurisdiction over a subsidiary, the judgment would only apply to the subsidiary and not the parent company. As such, criminal prosecutions may have limited publicity effect and minimal real impact on the larger corporation. Similarly, civil judgments may be difficult to enforce given a lack of resources contained at the subsidiary level and with no recourse as against the parent corporation.

While potentially problematic, it may be possible to overcome these five general difficulties to the extra-territorial application of domestic labour laws. In relation to the first two obstacles (international comity and consistency of laws), the solution to these problems have already been achieved through the current pursuit of core labour standards. In particular, international standards have already been accepted by all nations through their participation in the ILO. In addition, these standards do not reflect the politics of a particular state the way that Helms-Burton internationalizes the peculiar US obsession with Cuba. The core ILO norms and stipulated rules are agreed upon by the international community. The innovation of the extra-territorial approach is that these universally agreed upon rules would be enforced domestically in Northern states for violations anywhere in the world. In addition, Northern states' legal action would bolster the enforcement capability of Southern states which may not be eager to prosecute because they fear driving away foreign investment.

The third obstacle, the threat of divestment would be lessened if extra-territorial action was taken on in a concerted effort or if it was adopted by the major economic powers. If a country such as Canada unilaterally began holding its TNCs responsible for labour violations abroad, it would run the risk that a number of corporations would divest in the country. However, if the United States and the EU were to take such action, it is much less likely to be a problem. TNCs continue to have a home nationality and rely upon regional markets and political assistance of Western states. For most corporations there are many advantages to being a US or EU company that would not be outweighed by having to live up to basic labour rights. A complicating factor is the rise of global corporations outside of the OECD. What are the impacts on competition if these companies do not face similar national regulation?

The fourth problem, the inability to gather sufficient evidence in order to successfully advance a claim in the courts, greatly hampers the effectiveness of the extension of domestic laws and jurisdiction beyond the borders of the state. However, while this need to gather evidence would place a burden upon labour movements, it is not an insurmountable problem. A mechanism already exists for nationals outside of OECD 
countries to advance claims for the violation of labour, environmental and social rights against OECD TNCs within OECD states themselves. The OECD Guidelines for Multinationals were revised in 1998 and 2000 and further empowered a set of institutions and rights for citizens outside the OECD (OECD 2000). As a result of the revisions, National Contact Points (NCP) have been established in all OECD states to provide a space for people, including persons from non-OECD states, to make claims against the multinationals of OECD states and to publish their activities on an annual basis. Thus, women workers in a Sri Lankan export processing zone can take their case against a Korean TNC to the NCP in Seoul or Ecuadorian mine workers can advance a claim against Canadian TNCs to the NCP in Ottawa and the results of such proceedings will be published yearly.

The problem with NCPs and the Guidelines process has not been an inability on the part of claimants to uncover sufficient evidence to support their claims, but rather the voluntary nature of the process (parties do not have to participate if they do not wish to do so), the role of the NCP (acts solely as a facilitator in attempting to resolve the conflict through mediation) and the advisory nature of the Guidelines themselves. For example, the NCP statement concerning the filing of a complaint against Ivanhoe Mines Ltd. by the Canadian Labour Congress confirms these difficulties - no agreement could be reached between the parties to participate in the process, the NCP's involvement was limited to trying to facilitate a dialogue between the parties and the Canadian government only expected and encouraged Canadian companies to observe the guidelines (OECD 2002). Accordingly, it is not the evidentiary requirement that has prevented claims concerning the actions of TNCs from being resolved through this process, but rather that the forum itself cannot be applied to actors that are not interested in resolving potential conflicts. As such, a more robust enforcement vehicle is required in these situations.

It should also be noted that in addition to the evidentiary requirement problem facing the pursuit of enforceable labour standards, there are other obstacles presented through a legal approach including the burden of proof, the need for service of proceedings on the TNCs in the jurisdiction of the courts and possible defences that could be raised to in both criminal and civil claims. However, as with the evidentiary problem, these difficulties could also be overcome if the appropriate forum for advancing these causes of action were available.

The fifth and final obstacle facing an extension of domestic law is the legal character of the various actors involved. This obstacle cannot be overcome solely through the diligence and efforts of the labour movement or any other global or local movement or organization. In the absence of reform of the manner in which all domestic legal systems treat corporate entities or a stronger legal doctrine that permits the 'piercing of the corporate veil', attempts to pursue legal remedies against multinational corporations will remain relatively limited and ineffectual in most circumstances. 


\section{Moving Forward}

Drawing upon the history of previous internationalist practice and the experience of the core labour standards experience, labour groups in the West should consider how they can advance a strategy which takes account of worker's concerns in other states, reduces inter-state tension and keeps an independent stance toward their own state's foreign policy. This article has argued that an internationalist response from Western labour movements to the integration of China and India's labour force into the global economy should entail some consideration of what Western labour movements can do inside their own territory to control Western TNCs. In comparative terms, labour movements in China and India face much larger challenges than their Western counterparts. Thus, while Western labour has been under constant attack for the past thirty years, it still has greater financial resources and ability to influence the global agenda.

The previous analysis has suggested one possible way Western labour groups could improve the situation - pressing for TNCs to be held accountable for their actions in their home states. The outlines for such a development are present, but key changes are needed. The principle that Western citizens should be held responsible for the commission of particular crimes in foreign jurisdictions has already been established and has been applied to at least one major multi-national corporation in Chiquita Brands International Inc. This principle needs to be further extended to include corporations in relation to all criminal offences and broadened to include the violation of labour standards. Of course, there are immense challenges. Legal reforms will need to be introduced which hold corporations responsible for the actions of their subsidiaries and sub-contractors, both in domestic and international settings. This generates a series of technical issues in holding sub-contractors responsible in extended production chains. Courts will also need to recognize that even though formal mechanisms might exist to deal with these issues in developing countries, the difficulty of prosecuting transnational corporations shifts the enforcement burden to Western states.

Such a change to the legal architecture will be vigorously opposed by the most powerful economic actors on the planet. This will require a sophisticated political strategy involving splitting off 'good' corporations from 'bad' ones, demonstrating the financial reward of good labour practices through consumer action, threatening corporate interests in trade or investment agreements and offering corporations the certainty of a robust legal environment which punishes wrong doing. This article argues that an internationalist response which builds solidarity between workers and opens up the possibilities for greater co-operation in the future should target the offenders of labour rights - the TNCs and their suppliers. India and China are large states which might resent the application of extraterritorial law on Western corporations operating in their jurisdictions. Yet, by focusing Western labour activity on Western based TNCs, the conflict generated by a direct attack on the policies of other states should be mitigated.

There are many dimensions of labour internationalism and corporate regulation that this paper has not been able to address. We have not been able to give an in-depth analysis of the many market based attempts at corporate regulation. We have not been able to explore 
the supply chain relationship in China or India in any detail. The recent debate about reforms of Chinese labour laws and the transnational politics they generated are also beyond the scope of our study. We have, however, suggested that it is in the interest of internationalist minded Western labour groups to push for increased national regulation of Western TNCs. Even if Western labour movements are less than successful in changing the legal structure to hold Western TNCs accountable, the struggle to do so can bear fruit. It would simultaneously build solidarity in the movement of movements by demonstrating the goodwill and good sense of Western workers and put pressure on the nationalistic approaches of their own states. This goes some way to meeting the interests of workers in the North, South, East and West.

\section{NOTES}

${ }^{1}$ The authors would like to thank the anonymous reviewers for their insightful comments. We regret that space limitations prevented us from responding fully to all of their suggestions.

${ }^{2}$ A Trotskyist Fourth International was formed in 1938 but never achieved widespread support and suffered from continual infighting and splits.

${ }^{3}$ Since this article focuses upon attempts at creating enforceable labour rights, it largely ignores the role of the ILO. The ILO contributes to labour rights in other ways.

${ }^{4}$ The persuasiveness of extraterritoriality varies according to the nature of domestic legal systems with civil law, as in continental Europe, tending to be more likely to extend jurisdiction over citizens abroad than common law systems. For example, courts in the UK, Canada and the United States have all held that extra-territorial jurisdiction can only arise where the government has clearly and explicitly indicated that its statute is to apply to persons or events that are located beyond the borders of the state (Hogg 2002: 297-9).

${ }^{5}$ A related concept arising out of antitrust litigation and securities and exchange laws in the United States is what as known as the 'effects' doctrine, which holds that any transaction that has an 'effect' on domestic commerce in the United States falls within the jurisdiction of the US Courts. There is an ongoing dispute within the US courts as to how grave the 'effect' must be before jurisdiction is provided within the US, with some holding that there must be a substantial, direct and intended effect while others have adopted less onerous standards (HLR 1985).

${ }^{6}$ In the UK, see the Sexual Offences Act 2003, 2003 Chapter 42, the Crimes (Child Sex Tourism) Amendment Act 1994 in Australia and Amendments to the Canadian Criminal Code in 1997 and 2002.

${ }^{7}$ For example, sec. 72 of the UK. Sexual Offences Act 2003 specifically indicates that any offences committed outside of the UK and that are contrary to both the criminal law in the host country and UK (double criminality principle) creates an offence in the UK in relation to British citizens and residents of the UK. 
${ }^{8}$ Filartiga v. Pena-Irala $630 \mathrm{~F} 2 \mathrm{~d} 876$ at 878 . Significantly, the defendant was residing in the United States and served with the claim by the Filartiga family in the US before he was deported to Paraguay by the United States, thereby fulfilling the personal jurisdiction requirement necessary for the court to entertain the proceedings.

${ }^{9}$ Kadic v. Karadzic 70 F3d 232 at 245.

${ }^{10}$ Doe V v. Unocal Corp., 110 F.Supp. 2d 1294 (C.D. Cal. 2000) and Doe VI v. Unocal, No. 00-56603, 2002 WL 31063976, (9 $9^{\text {th }}$ Cir. 18 September 2002).

${ }^{11}$ Sosa v. Alvarez-Machain, 124 S. Ct. 2739 (2004) at 2761. In this case, the Supreme Court dismissed the plaintiffs claim based on allegations of unlawful and arbitrary detention, on the basis that the actions giving rise to the plaintiffs complaint had not yet attained the applicable status in international law so as to constitute a violation of the law of nations.

${ }^{12}$ In addition, the Act explicitly directed the US courts to determine claims for liability under title III on the merits of each case by specifically removing the Act of State doctrine as a defence available to foreign defendants (Lowe 1997: 379-81).

${ }^{13}$ For example, see Weinstein v. Islamic Republic of Iran, 184 F.Supp. $2 d 13$ (D.O.C. 2002) and Daliberti v. Republic of Iran, 97 F.Supp. 2d 13 (D.O.C. 2000).

14 'Predictability and Comity: Toward Common Principles of Extraterritoriality', pages 1320-1321.

${ }^{15}$ Wilson, 'Beyond Unocal', page 64. As noted above, the claims against Total in the Doe v. Unocal litigations were dismissed due to the lack of personal jurisdiction over Total, despite the presence of a subsidiary within the Court's jurisdiction.

\section{REFERENCES}

Adler, G. and Webster, E. (1995) 'Challenging Transition Theory: The Labour Movement, Radical Reform, and Transition to Democracy in South Africa', Politics and Society 23(1): 75-106.

Bielasiak, J. and B. Hicks. (1990) 'Solidarity's Self-organization: the Crisis of Rationality and Legitimacy in Poland, 1980-81', East European Politics and Societies 4(3): 489-512.

Blowfield, M. (1999) 'Ethical Trade: A Review of Developments and Issues', Third World Quarterly 20(4): 753-770.

Blumberg, P.I. (2001) 'Accountability of Multinational Corporations: The Barriers Presented by Concepts of the Corporate Juridical Entity', Hastings International and Comparative Law Review 24(3): 297-320.

Bowles, P. and Harris, J. (2008) 'Notes for the Special Issue of Global Labour Journal on: "Globalization(s) and Labour in China and India: Impacts and Responses", unpublished. 
Bruno, K. and Karliner, J. (2002) Earthsummit.biz: The Corporate Takeover of Sustainable Development. Oakland, CA: Food First Books.

Chanin, J.M. (2005) 'The Regulatory Grass is Greener: A Comparative Analysis of the Alien Tort Claims Act and the European Union's Green Paper on Corporate and Social Responsibility', Indiana Journal of Global Legal Studies 12(2): 745-778.

Christian Aid (2004) Behind the Mask: The Real Face of Corporate Social Responsibility. London: Christian Aid.

Colas, A. (1994) 'Putting Cosmopolitanism into Practice: The Case of Socialist Internationalism', Millennium 23(3): 513-34.

Collingsworth, T. (2003) 'Using the Alien Tort Claims Act to Introduce the Rule of Law to the Global Economy', International Labour Rights Fund. http://www.iradvocates.org/collingsworth220605.pdf

Davidow, J. (2002) 'International Implications of US Antitrust in the George W. Bush Era', World Competition 25(4): 493-507.

Deyo, F.C. (1993) Beneath the Miracle: Labor Subordination in the New Asian Industrialism. Berkley: University of California Press.

Eder, M. (1997) 'Shop Floor Politics and Labor Movements: Democratization in Brazil and South Korea', Critical Sociology 23(2): 3-31.

Forman, M. (1998) Nationalism and the International Labor Movement: The Idea of the Nation in Socialist and Anarchist Theory. University Park P.A: Pennsylvania State University Press.

Halliday, F. (1988) 'Three Concepts of Internationalism', International Affairs 64(2): 187-98.

HLR (1985) 'Predictability and Comity: Toward Common Principles of Extraterritorial Jurisdiction', Harvard Law Review 98(6): 1310-1330.

HLR (1989) 'The Extraterritorial Applicability of the Fourth Amendment', Harvard Law Review 102(7): 1672-1694. 
Hobsbawm, E.J. (1988) 'Working Class Internationalism', in F. Van Holthoon and M. Van Der Linden (eds), Internationalism in the Labour Movement 1830-1940 Volume 1 (pp. 2-16). Leiden: E.J Brill.

Hogg, P. (2002) Constitutional Law of Canada. Toronto: Carswell.

Lichtblau, E. and Dao, J. (2004) 'US is Now Pursuing Americans Who Commit Sex Crimes Overseas' The New York Times, 8 June 2004.

Lowe, A.V, 'US. Extraterritorial Jurisdiction: The Helms-Burton and D'Amato Acts', The International Law and Comparative Law Quarterly 46(2): 378-390.

Lynch, C. (1999) 'The Promise and Perils of Internationalism', Global Governance 5(1): $18-102$.

McMichael, P. (2007) Development and Social Change: A Global Perspective. London: Sage.

Ochoa, C. (2005) 'Access to US Federal Courts as a Forum for Human Rights Disputes: Pluralism and the Alien Tort Claims Act', Indiana Journal of Global Legal Studies 12(2): 631-650.

O’Brien, R. (2008) 'No Safe Havens: Labour, Regional Integration and Globalization' in A.F. Cooper, C.W. Hughes and P. De Lombaerde (eds), Regionalization and Global Governance: The Taming of Globalization? (pp. 142-56). New York: Routledge.

O'Brien, R., Goetz, A.M., Aart Scholte, J. and Williams, M. (2000) Contesting Global Governance: Multilateral Economic Institutions and Global Social Movements. Cambridge: Cambridge University Press.

OECD (2000) The OECD Guidelines for Multinational Enterprises. Paris: OECD. www.oecd.org.

OECD (2002) Statement of National Contact Point for Canada. Ivanhoe Mines Ltd. and the Canadian Labour Congress. http://www.oecd.org/dataoecd/20/24/37205653.pdf

Rowe, J.K. (2005) 'Corporate Social Responsibility as Business Strategy', in R. Lipschutz and J.K. Rowe (eds) Globalization, Governmentality and Global Politics: Regulation for the Rest of Us? London: Routledge.

Roy, J. (1997) 'The Helms-Burton Law: Development, Consequences, and Legacy for Inter-American and European-US. Relations', Journal of International Studies and World Affairs 39(3): 77-108. 
Sell, S.K. (2005) 'Big Business the WTO and Development: Uruguay and Beyond' in R. Stubbs and G.R.D. Underhill (eds), Political Economy and the Changing Global Order (pp. 183-97). Don Mills: Oxford.

Shachor-Landau, C. (1980) 'Extra-Territorial Penal Jurisdiction and Extradition', The International and Comparative Law Quarterly 29(2/3): 274-295.

Shamir, R. (2004) 'Between Self-Regulation and the Alien Tort Claims Act: On the Contested Concept of Corporate Social Responsibility' Law and Society Review 38(4): 635-664.

Silverman, V. (2000) Imagining Internationalism in American and British Labor, 1939-49. Chicago: University of Illinois Press.

Sims, B. (1992) Workers of the World Undermined: American Labor's Role in US. Foreign Policy. Boston: South End Press.

Smis, S. and van der Borght, K. (1999) 'The EU-US. Compromise on the Helms-Burton and D'Amato Acts' The American Journal of International Law 93(1): 227-236.

Stessens, G. (2000) Money Laundering: A New International Law Enforcement Model. Cambridge: Cambridge University Press.

Stubbs, R. (2005) Rethinking Asia's Economic Miracle: The Political Economy of War, Prosperity and Crisis. Basingstoke: Palgrave Macmillan.

Thomson, D. and Larson, R. (1978) Where Were You, Brother? An Account of Trade Union Imperialism. London: War on Want.

USDDC (2007) 'United States of America v. Chiquita Brands International, Inc.,' 14 March, US.D.D.C., Lambert, J. R.C.L., No. 07-055.

Vosko, L. (2000) Temporary Work: The Gendered Rise of a Precarious Employment Relationship. Toronto: University of Toronto Press.

Waterman, P. (1998) Globalization, Social Movements and the New Internationalisms. London: Mansell.

Williams, M. (1994). International Economic Organizations and the Third World. London: Harvester Wheatsheaf. 
Wilson, A. (2006) 'Beyond Unocal: Conceptual Problems in Using International Norms To Hold Transnational Corporations Liable under the Alien Tort Claims Act' in O. De Schutter (ed), Transnational Corporations and Human Rights. Portland: Hart Publishing.

\section{BIOGRAPHICAL NOTE}

Greg Flynn is a lawyer and an assistant professor of Political Science at McMaster University. He graduated with a PhD from McMaster University in May 2009 with a specialization in comparative public policy. His research focuses on the role of the courts, law and legal process in policy-making and citizen engagement in democratic institutions and practices, including political parties and elections.

Robert O'Brien is the LIUNA-Mancinelli Professor of Global Labour Issues and Chair of the Department of Political Science at McMaster University. He teaches courses in international relations and global political economy. His books include: Solidarity First: Canadian Workers and Social Cohesion (UBC Press 2008); with M. Williams, Global Political Economy: Evolution and Dynamics $2^{\text {nd }}$ ed. (Palgrave 2007); with Paul James Globalizing Labour (Sage 2007); and with Jan Aart Sholte A.M. Goetz and Marc Williams, Contesting Global Governance: Multilateral Economic Institutions and Global Social Movements (Cambridge 2000). He is also co-editor of the journal Global Social Policy. 